\title{
Tingkat Kepuasan Konsumen terhadap Mutu Beras di Kampung Bunga Raya Kabupaten Siak
}

\section{Level of Customer Satisfaction on The Quality of Rice in Kampung Bunga Raya Siak District}

\author{
Asgami Putri \\ Fakultas Pertanian, Universitas Lancang Kuning, asgami@unilak.ac.id
}

\begin{abstract}
Abstrak
Tujuan penelitian ini mengetahui tingkat kepentingan dan kepuasan konsumen terhadap atribut mutu beras. Penelitian dilaksanakan di Kampung Bunga Raya Kabepaten Siak. Sampel yang diambil sebanyak 120 orang. Metode penelitian yanng digunakan adalah accidental sampling. Pengumpulan data dilakukan dengan wawancara. Analisis yang digunakan dalam penelitian adalah analisis Important Performance Analysis (IPA), analisis Customer Satisfaction Index (CSI). Hasil penelitian Atribut beras yang menjadi prioritas utama bagi produsen untuk memperbaikinya karena atribut tersebut sangat mempengaruhi kepuasan konsumen dalam membeli beras. Indicator atau atribut tersebut adalah kebersihan beras dan kemasan beras. Sedangkan indicator yang telah dapat memuaskan konsumen dan harus dipertahankan oleh produsen agar konsumen tetap puas dalam membeli beras itu antara lain atribut gizi beras, rasa beras, dan bau beras.
\end{abstract}

Kata Kunci: analisis kepuasan konsumen, mutu beras

\section{Abstract}

This study aims to determine the level of importance and customer satisfaction with the quality attributes of rice. This research was carried out in Bunga Raya Kabepaten Village, Siak. Samples taken were 120 people. The research method used is accidental sampling. Data collection is done by interview. The analysis used in the study was an analysis of Important Performance Analysis (IPA), an analysis of the Customer Satisfaction Index (CSI). Research results The attributes of rice are a top priority for producers to improve. Because these attributes greatly affect consumer satisfaction in buying rice. These indicators or attributes are rice rice and rice packaging. While indicators that must be able to satisfy consumers and must be approved by consumers to remain satisfied to buy rice include the attributes of rice, the taste of rice, and the smell of rice.

Keywords: analysis of costumer satisfaction, quality of rice 


\section{Pendahuluan}

Beras adalah makanan pokok yang dikonsumsi oleh sebagian besar penduduk Indonesia. Menurut Sawit (2000) dalam [1], beras harus dilihat sebagai barang publik, yang tidak dapat digunakan sebagai barang pribadi tetapi juga barang publik. Banyak kepentingan publik dihasilkan oleh beras, dan beras penting untuk ketahanan pangan, keamanan ekonomi, dan lapangan kerja. Faktanya, menurut penelitian Timmer (1996) dalam [2], secara empiris membuktikan bahwa pertumbuhan ekonomi dan ketahanan pangan berkaitan erat, menyimpulkan bahwa tidak ada negara yang dapat mempertahankan pertumbuhan ekonomi tanpa terlebih dahulu menyelesaikan masalah ketahanan pangan.

Beras dipilih menjadi pangan pokok karena sumber daya alam lingkungan mendukung penyediaannya dalam jumlah yang cukup, mudah dan, cepat pengolahannya, memberi kenikmatan pada saat menyantap, dan aman dari segi kesehatan. Sesungguhnya rasa lapar dapat dipuaskan dengan memakan makanan apa saja, terutama makanan sumber pati atau lazimnya disebut karbohidrat. Namun perlu diperhatikan, dalam konsep makan, terdapat dua unsur yang dianut oleh kebanyakan orang yaitu kenyang dan nikmat.

Beras yang dijual di pasar bermacam-macam jenisnya dan berbeda-beda pula mutunya. Mutu beras dapat juga dibagi atas varietas unggul varietas unggul nasional maupun varietas unggul lokal. Varietas Unggul Nasional adalah varietas yang dapat ditanam berkali-kali dengan baik. Hasil dari panen varietas ini bisa dijadikan benih kembali. Ada petani yang bisa menanam hingga 10 kali lipat dengan hasil yang lebih sama. Varietas padi unggul biasanya telah dilepas oleh pemerintah dengan SK Menteri Pertanian. Varietas ini telah melewati berbagai uji coba. Harga benih verietas ini murah, harganya bisa mencapai 5 ribu- 10 ribu per kilogram [3]. Contoh dari varietas beras unggul nasional yang ditanam petani adalah ciherang (bisa mencapai $47 \%$ dari total varietas yang ditanam), IR-64, Mekongga, Cimelati, Cibogo, Cisadane, Situ Patenggang, Cigeulis, Ciliwung, Membramo, Sintanur, Jati luhur, Fatmawati, Situ bagendit, dan lain-lain. Sejak tahun 2008, penamaan padi berubah. Untuk padi sawah dinamakan Inpari (Inbrid Padi Irigasi). Contoh: Inpari 1-10, Inpari 11, Inpari 12 dan Inpari 13, dan lain-lain. Sementara dari pihak BATAN telah mengeluarkan varietas padi: Cilosari, Diahsuci, Bestari, Inpari Sidenuk, Pandan Putri dll [3]. Varietas padi lokal adalah varietas padi yang telah lama dikirim di daerah tertentu. Lokasi ini memiliki ciri khas. Setiap varietas memiliki keunggulan dan kelemahan. Demikian juga untuk varietas lokal tersebut. Beras lokal Indonesia memiliki banyak varietas unggul yang bercita rasa unik. Rojo lele, anak daro, beras solok, pandan wangi, dan masih banyak jenis lainnya. Selain enak dimakan dan dicicipi, beras-beras ini juga punya manfaat lebih untuk kesehatan [4].

Memahami pentingnya konsumen adalah tugas penting bagi pemasar. Pemasar mencoba memahami pembelian konsumen sehingga mereka dapat menawarkan kepuasan yang lebih besar kepada konsumen. Tetapi konsumen belum memuaskan sampai batas tertentu masih akan ada. Beberapa pemasar masih belum fokus pada konsep pemasaran sehingga mereka tidak berorientasi pada konsumen dan tidak memandang kepuasan pelanggan sebagai tujuan utama. Lebih lanjut, karena cara menganalisis konsumen tidak pasti, pemasar tidak perlu menyetujui apa yang dapat memuaskan pembeli. Meskipun untuk mengetahui faktor-faktor yang meningkatkan kepuasan pelanggan, mereka belum puas untuk memenuhi faktor-faktor ini.

Bagi petani walaupun tidak berkaitan secara langsung dengan konsumen tetapi dengan mengetahui apa selera dan keinginan konsumen terhadap beras dapat member gambaran jenis padi apa yang akan ditanam berdasarkan dengan kepuasan dan selera konsumen. Dengan begitu petani akan memproduksi beras yang diinginkan oleh konsumen bukan jenis beras yang itu-itu saja.

Setiap konsumen akan menghabiskan atau mengalokasikan pendapatannya untuk membeli barang-barang konsumsi dan layanan konsumsi untuk memenuhi kebutuhan mereka. Teori kepuasan konsumen akan membahas apa reaksi konsumen dalam kesediaan mereka untuk membeli barang ketika ada perubahan pendapatan yang mereka peroleh; ketika ada perubahan harga barang yang diambil, ketika ada perubahan selera konsumen itu sendiri. Setiap konsumen memiliki alasan tertentu. Ingin membeli barang kebutuhan. Apakah itu benar-benar suatu kebutuhan atau hanya keinginan belaka. Berbeda dengan beras primer yang merupakan kebutuhan primer, tanpa beras masyarakat tidak dapat hidup. Ini telah menjadi pertimbangan bagi masyarakat Indonesia, karena beras merupakan barang yang harus dimiliki oleh semua orang. Sebelum membeli beras, pembeli 
pasti mencari tahu tentang berbagai hal, baik kualitas beras, harga beras, kemasan beras, tempat membeli beras dengan kualitas baik, tetapi harga yang ditawarkan murah

\section{Metode Penelitian}

Penelitian ini dilakukan di Kampung Bunga Raya, Kabupaten Siak. Daerah ini merupakan pusat penghasil beras di Provinsi Riau. Jenis padi yang ditanam di daerah ini adalah logawa, ciherang, dan INPARI. Jenis beras yang dikonsumsi oleh masyarakat sekitar adalah jenis beras pulen, hal ini disebabkan kenyataan bahwa mayoritas penduduk di desa ini adalah masyarakat transmigran yang memiliki kesukaan terhadap beras pulen, sesuai dengan hasil penelitian sebelumnya. dilakukan pada tahun 2014 dan orang Jawa menyukai nasi pulen [5]. Analisis yang digunakan dalam penelitian ini adalah analisis IPA (Important Performance Analysis) dimana analisis ini membandingkan tingkat kepentingan dengan tingkat harapan konsumen. Analisis yang digunakan untuk menentukan tingkat kepuasan pelanggan dengan produk beras di desa bunga menggunakan analisis statistik deskriptif kualitatif dan statistik kuantitatif, yaitu importance and performance [6]. Dengan tingkat kesesuaian ini, tingkat kepuasan pelanggan dapat diketahui. Jika nilai total sesuai (total 100\%) maka dapat diterima konsumen untuk sangat puas. Jika tingkat kesesuaian sama dengan rata-rata total $(=100 \%)$, maka dapat diterima konsumen untuk puas. Nilai total $(<100 \%)$ dapat diterima bahwa konsumen tidak puas. Hasil perhitungan pembobotan kemudian diratakan dan diformulasikan ke dalam diagram Cartesian. Setiap atribut diposisikan dalam diagram. Skor rata-rata pada tingkat kinerja $\left(\mathrm{X}^{\bar{T}}\right.$ menunjukkan posisi atribut $\mathrm{X}$, sedangkan atribut posisi pada sumbu $\mathrm{Y}$ bertentangan dengan nilai rata-rata kepentingan konsumen $(\mathrm{Y})$.

Hasil dari perhitungan pembobotan tersebut kemudian diratakan dan diformulasikan kedalam diagram kartesius. Masing-masing atribut diposisikan kedalam sebuah diagram. Skor ratarata penilaian terhadap tingkat kinerja $(\bar{X})$ menunjukkan posisi atribut sumbu $\mathrm{X}$, sementara posisi atribut pada sumbu Y ditunjukkan dengan nilai rata-rata tingkat kepentingan konsumen $(\bar{Y})$. Hasil ini dapat diperoleh dengan formula sebagai berikut :

$$
\begin{aligned}
& \overline{X i}=\sum X i \\
& \mathrm{n} \\
& \bar{Y} i=\sum_{\mathrm{n}} v i
\end{aligned}
$$

Diagram kartesius ini merupakan suatu bangun yang dibagi menjadi empat bagian. Bangun ini dibatasi dua garis yang berpotongan tegak lurus denga titik koordinat $(\overline{\bar{X}}, \overline{\bar{Y}})$$$
\overline{\overline{X i}}=\sum \overline{\mathrm{X}}
$$$$
\overline{\bar{Y}} i=\sum_{\mathrm{K}} \bar{Y} i
$$
Dimana :
$\mathrm{K}$ = banyaknya atribut yang mempengaruhi kepuasan konsumen
$\overline{\bar{X}}=$ rata-rata dari rata-rata bobot skor penilaian kinerja ptoduk
$\overline{\bar{Y}}=$ rata-rata dari rata-rata bobot kepentingan dari seluruh responden 


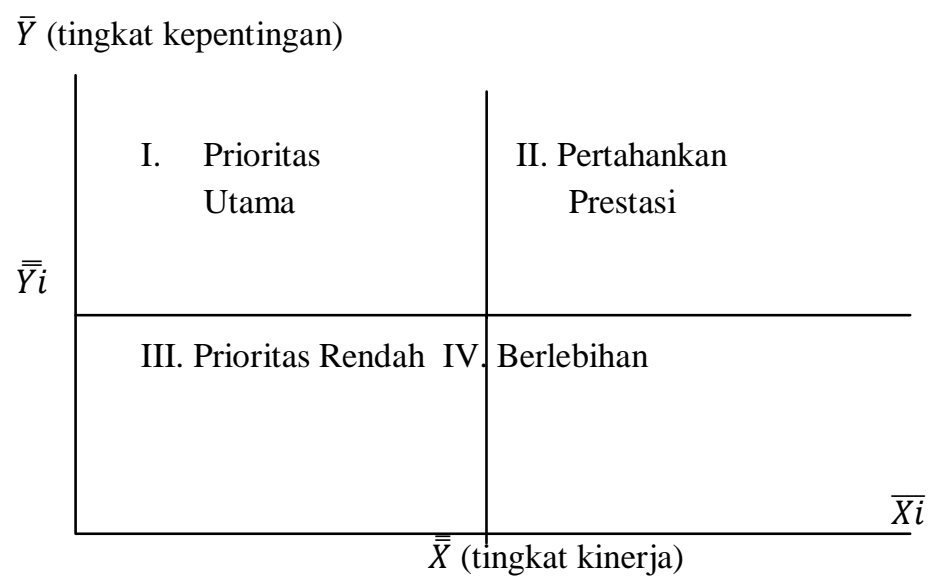

Gambar 1. Diagram Cartesius

Hasil perhitungan nilai tersebut kemudian digunakan sebagai pasangan koordinat titik-titik atribut yang memposisikan suatu atribut pada diagram kartesius. Setiap hasil hasil akan menempati salah satu kuadran dalam diagram katesius tersebut yang terdiri atas :

a. Prioritas Utama (I)

Merupakan wilayah yang mengandung faktor-faktor yang dianggap penting oleh konsumen.

Namun pada kenyataannya faktor-faktor ini tidak seperti yang diharapkan oleh konsumen

(tingkat kepuasan yang diperoleh masih sangat rendah) sehingga kinerja atribut yang masuk ke dalam kuadran ini harus ditingkatkan (tingkat kepentingan tinggi sementara tingkat kinerja rendah).

b. Pertahankan Prestasi (II)

Merupakan wilayah yang mengandung faktor-faktor yang dianggap penting oleh dan faktorfaktor ini sesuai dengan apa yang dirasakan oleh konsumen, sehingga tingkat kepuasan pelanggan relatif tinggi. Atribut yang termasuk dalam kuadran ini harus dipertahankan, karena semua variabel ini membuat produk unggul di mata konsumen (kepentingan tinggi dan kinerja tinggi).

c. Prioritas Rendah (III)

Merupakan wilayah yang memuat faktor-faktor yang dianggap kurang penting oleh konsumen dan pada kenyataannya kinerjanya pun tidak istimewa. Peningkatan-peningkatan atribut yang termasuk kedalam kuadran dapat dipertimbangkan kembali karena pengaruhnya terhadap manfaat yang dirasakan oleh konsumen sangat kecil.

d. Berlebihan (IV)

Merupakan wilayah yang memuat atribut-atribut yang dianggap kurang oleh konsumen dan dirasakan terlalu berlebihan. Atribut yang terdapat pada kuadran ini sebaiknya dikurangi oleh pihak perusahaan karena dapat mengurangi biaya atau menghemat biaya perusahaan

Atribut indicator yang akan diteliti antara lain :

a. Rasa beras

b. Gizi beras

c. Kemasan beras

d. Warna beras

e. Aroma nasi

f. Kebersihan beras

g. Bau beras 


\section{Hasil dan Pembahasan}

Dari hasil penelitian yang dilaksanakan diketahui bahwa beras yang biasa dikonsumsi oleh masyarakat Kampung Bunga Raya Kabupaten Siak adalah jenis logawa dimana jenis beras ini adalah jenis beras yang banyak ditanam di Bunga Raya dan juga merupakan beras pokok yang dikonsumsi oleh masyarakat sekitar. Masyarakat biasanya langsung membeli ke heller atau ke warung-warung terdekat. Di kampung tersebut banyak memiliki heller yang berupa bangunan dan ada juga yang berkeliling. Heller keliling ini membantu masyarakat dalam penggilingan padi. Beras yang dihasilkan oleh masyarakat dijual ataupun dikonsumsi sendiri oleh masyarakat tersebut. Sehingga jenis beras yang banyak ditemukan dipasaran di dearah Kampung Raya Kabupaten Siak adalah jenis logawa. Atribut atau indikator yang digunakan antara lain rasa beras, gizi yang terkandung, kemasan beras, warna beras, aroma beras, kualitas beras, bau beras. Untuk lebih jelas dapat dilihat pada Tabel 1.

Tabel 1. Nilai Bobot Rataan Tingkat Kinerja dan Tingkat Kepentingan Beras

\begin{tabular}{|c|c|c|c|c|c|c|c|}
\hline \multirow{2}{*}{ No } & \multirow{2}{*}{$\begin{array}{c}\text { Atribut Pelayanan } \\
\text { Mutu }\end{array}$} & \multirow{2}{*}{$\begin{array}{l}\text { Rataan Ting. } \\
\text { Kepentingan }\end{array}$} & \multirow{2}{*}{$\begin{array}{c}\text { Rataan Ting. } \\
\text { Kinerja }\end{array}$} & \multirow{2}{*}{$\begin{array}{l}\text { Weighted } \\
\text { Factor }\end{array}$} & \multirow{2}{*}{$\begin{array}{l}\text { Weighted } \\
\text { Score }\end{array}$} & \multicolumn{2}{|c|}{ Ting. Kepuasan } \\
\hline & & & & & & $\begin{array}{c}\text { Rasio } \\
(\%)\end{array}$ & Ket \\
\hline A & Rasa beras & 2.20 & 3.30 & 0.1 & 0,33 & 150 & Sangat Puas \\
\hline $\mathrm{B}$ & Gizi beras & 3.64 & 3.64 & 0.16 & 0.6 & 100 & Puas \\
\hline $\mathrm{C}$ & Kemasan beras & 3.20 & 3.20 & 0.15 & 0.50 & 100 & Puas \\
\hline $\mathrm{D}$ & Warna beras & 2.35 & 2.35 & 0.11 & 0.25 & 100 & Puas \\
\hline$E$ & Aroma nasi & 3.37 & 3.37 & 0.15 & 0.51 & 100 & Puas \\
\hline $\mathrm{F}$ & Kebersihan Beras & 3.39 & 3.25 & 0.15 & 0.5 & 95.8 & Tidak Puas \\
\hline $\mathrm{G}$ & Bau beras & 3.94 & 3.94 & 0.18 & 0.7 & 100 & Puas \\
\hline & Total & 22.09 & 23.05 & 1 & 3.39 & & \\
\hline & Rataan & 3.16 & 3.29 & & & & \\
\hline
\end{tabular}

Dari Tabel 1 diketahui nilai perhitungan masing-masing atribut diposisikan kedalam sebuah diagram. Skor rata-rata penilaian terhadap tingkat kinerja $(\bar{X})$ menunjukkan posisi atribut sumbu $X$ yaitu dengan nilai 3,31, sementara posisi atribut pada sumbu Y ditunjukkan dengan nilai rata-rata tingkat kepentingan konsumen $(\bar{Y})$ yaitu dengan nilai 3,18. dari tabel diatas diketahui secara deskriptif bahwa aroma nasi yang dimaksud adalah aroma yang dihasilkan oleh beras ketika beras selesai dimasak dan telah menjadi nasi yang siap untuk dikonsumsi. Sebenarnya aroma nasi ini adalah masalah selera yang berbeda antara satu dengan yang lain. Sebagian suku yang ada di pulau Sumatera lebih menyukai beras yang tidak memiliki aroma. Dari pembahasan diatas diketahui beras untuk atribut aroma beras responden mengatakan bahwa atribut ini sudah memuaskan mereka terbukti dari persentase perbandingan antara tingkat kinerja dan tingkat kepentingan, dimana tingkat kinerja lebih tinggi dibandingkan tingkat kepentingannya.

Suatu makanan yang baik dikonsumsi apabila terkandung gizi yang baik bagi manusia jika makanan tersebut dikonsumsi. Beras merupakan makanan pokok bagi manusia, hal ini memang ada sebabnya karena beras memiliki vitamin yang kompleks yang sangat bergguna bagi tubuh manusia. Selain memiliki vitamin beras juga merupakan makanan yang mengenyangkan dan merupakan sumber tenaga atau energi yang dibutuhkan oleh tubuh manusia. Beras yang ada dipasaran telah memiliki gizi yang sangat baik untuk tubuh, dan bagi konsumen gizi pada beras merupakan hal penting dan masyarakat telah puas dengan gizi yang ada pada beras. Berdasarkan Tabel 1 diketahui bahwa Perbandingan antara skor tingkat kinerja dan skor tingkat kepentingan yang mengkonsumsi beras adalah 100 persen. Hal ini berarti tingkat kinerja sesuai dengan tingkat kepentingan responden. Sehingga konsumen merasa puas dengan gizi beras yang ada di pasaran. Hal ini disebabkan karena beras yang ada dipasaran memiliki tingkat gizi yang sama baik.

Kemasan beras yang dimaksud adalah tempat atau wadah yang menampung beras yang akan dijual. Di pasaran kemasan beras yang ada berupa plastik sintetis atau karung dengan berat yang beraneka ragam ada yang ukurannya $10 \mathrm{~kg}, 20 \mathrm{~kg}, 50 \mathrm{~kg}$ dan lainnya. Dengan beraneka ragamnya jenis kemasan dan ukurannya sehingga konsumen dapat memilih dengan leluasa kemasan apa yang akan dipilih dan ukuran apa yang diinginkan oleh konsumen.Untuk atribut kemasan beras hasil perbandingan antara skor tingkat kinerja dan skor tingkat kepentingan pada beras unggul lokal adalah 100 persen. Hal ini berarti tingkat kinerja sesuai dengan tingkat 
kepentingan responden. Sehingga konsumen merasa puas dengan atribut kemasan beras yang ada di pasaran. Lebih lanjut dapat dilihat pada tabel 1. Berdasarkan penjelasan diatas diketahui bahwa produk beras untuk atribut kemasan konsumen telah meras puas, karena dipasaran kemasan beras telah baik dan bersih. Selain itu ukuran kemasannya pun beraneka ragamam sehingga konsumen dapat memilih beras denagn ukuran kemasan apa saja sesuai dengan kemampuan konsumen.

Warna beras yang dimaksud adalah warna yang nampak pada bulir beras yaitu ada yang bewarna putih, ada yang berwarna merah dan ada juga yang warnanya hitam. Tetapi yang biasa dan yang diteliti adalah konsumsi beras yang berwarna putih. Di pasaran pun banyak beras karena beras yang berwarna putih sudah lazim dikonsumsi dan dipasaran banyak dijumpai beras yang berwarna putih selain itu harga beras yang berwarna putih lebih murah dibandingkan dengan dengan jenis beras yang berwarna selain putih. Untuk itu bagi sebagian konsumen warna beras tidak terlalu berpengaruh dalam meningkatkan kepuasan konsumen beras. Berdasarkan Tabel 1 diketahui bahwa Perbandingan antara skor tingkat kinerja dan skor tingkat kepentingan untuk adalah 100 persen. Hal ini berarti tingkat kinerja sesuai dengan tingkat kepentingan responden. Sehingga konsumen merasa puas dengan atribut warna beras yang ada di pasaran.Berdasarkan pembahasan diatas diketahui bahwa warna beras baik beras unggul lokal maupun beras unggul nasional sudah dapat memuaskan konsumen itu terbukti antara nilai tingkat kepentingan dan tingkat kinerja sama-sama tinggi.

Beras yang ada di pasaran memiliki banyak jenis dan varietas. Beras memiliki penggemarnya masing-masing. Suku minang, melayu, batak yang ada di Pekanbaru menyukai beras dengan jenis beras pera, sedangkan suku jawa dan tionghoa yang ada di Pekanbaru lebih menyukai beras pulen. Beras pera ini adalah jenis beras yang apabila telah dimasak beras tersebut akan berderai dan tidak lengket satu sama lainnya, sedangkan beras pulen apabila dimasak beras ini akan pulen. Rasa beras ini mempengaruhi tingkat kepuasan konsumen, karena menurut konsumen tingkat kepentingan untuk atribut rasa beras tinggi dan tingkat kinerjanya pun tinggi, karena jenis atau varietas beras yang ada dipasaran sesuai dengan keinginan konsumen yang beragam. Berdasarkan Tabel 1 diketahui bahwa perbandingan antara skor tingkat kinerja dan skor tingkat kepentingan untuk beras adalah 150 persen. Hal ini berarti tingkat kinerja sesuai dengan tingkat kepentingan responden. Sehingga konsumen merasa sangat puas dengan atribut rasa beras yang ada di pasaran. Hal ini disebabkan karena jenis beras pera dan beras pulen telah banyak beredar dipasaran sehingga konsumen dapat memilih sendiri beras apa yang akan mereka konsumsi.

Suatu produk yang akan dijual kepada konsumen harus memperhatikan kebersihan yang ada pada produk yang akan dijual. Dengan kebersihan produk yang baik maka konsumen akan puas dengan produk yang dijual dan mereka akan menjadi konsumen yang loyal terhadap produk tersebut. Sedangkan kualitas beras yang ada di pasaran masih sedikit rendah. Kebersihan beras yang dimaksud disini adalah masih banyak ditemukan sampah pada beras tersebut misalnya masih ditemukan batu kecil, gabah, pasir, dll. Walaupun beras menjadi barang kebutuhan pokok yang harus selalu dikonsumsi oleh masyarakat dan harus selalu dibeli oleh konsumen. Tidak ada salahnya beras yang ada dipasaran ditingkatkan lagi kualitasnya dengan diperhatikan keebersihan beras yang akan dijual kepasaran. Sehingga konsumen akan meras puas walaupun harga beras yang dijual mahal untuk sebagian masyarakat. Berdasarkan Tabel 1 diketahui bahwa Perbandingan antara skor tingkat kinerja dan skor tingkat kepentingan untuk beras adalah 95.87 persen. Hal ini berarti tingkat kinerja tidak sesuai atau kurang dibandingkan dengan tingkat kepentingan responden yang tinggi. Sehingga konsumen merasa tidak puas dengan kualitas beras yang ada di pasaran. Berdasarkan penjelasan diatas diketahui bahwa atribut kebersihan beras masih belum bisa memuaskan konsumen. Itu terbukti dari tingkat kepentingan lebih tinggi daripada nilai tingkat kinerja produk. Hal ini disebabkan masih banyaknya beras yang tidak bersih dari sampah atau yang tidak seharusnya ada didalam beras misalnya kerikil, plastik, bahkan ada juga beras yang mengandung kutu didalamnya, dll.

Bau beras yang dimaksud disini adalah bau yang diakibatkan apabila beras terlalu lama disimpan ditempat yang lembab yaitu akan timbul bau apek pada beras. Menurut konsumen apabila beras memiliki bau apek itu akan mengakibatkan nasi yang dihasilkan ketika beras dimasak cepat basi, dan beras tersubt tidak akan enak dan bahkan akan mengakibatkan sesuatu yang buruk bagi yang mengkonsumsinya. Berdasarkan Tabel 1 diketahui bahwa perbandingan antara skor tingkat kinerja dan skor tingkat kepentingan untuk beras adalah 100 persen. Hal ini berarti tingkat kinerja 
sesuai dengan tingkat kepentingan responden. Sehingga konsumen merasa puas dengan atribut bau beras yang ada di pasaran. Dari hasil penelitian diketahui bahwa sebagian besar masyarakat yang dijadikan responden telah merasa puas karena beras yang mereka konsumsi tidak memiliki bau apek tersebut.

Tingkat kepentingan dan tingkat kinerja yang dapat mempengaruhi tingkat kepuasan konsumen terhadap beras yang ada dipasaran dapat diketahui dengan menggunkan alat analisis Important Performance Analysis (IPA). Analisis ini dapat mengetahui faktor-faktor apa saja yang dianggap penting dan faktor apa saja yang kinerjanya masih dianggap rendah sehingga dapat mempengaruhi keptusan konsumen dalam membeli beras varietas tertentu dengan itu dapat mengingkatkan faktor yang dianggap kinerjanya kurang dan dapat membuat konsumen puas dengan beras yang ada.

Analisis ini memperoleh nilai yang dibutuhkan dengan menggunakan alat bantu yaitu kuesioner yang telah diisi oleh konsumen. Kuesioner berisi pertanyaan yang berhubungan dengan faktor yang berpengaruh terhadap tiigkat kepuasan konsumen. Nilai yang diperoleh tersebut akan dipetakan nilainya dalam diagram kartesius dan penyajiannya tersebut akan memberikan strtategi pemasaan yang tepat dalam hal pemasaran beras dan meningkatkan kepuasan konsumen terhadap beras.

Untuk lebih jelas tentang kepuasan konsumen tersebut kita akan menggunakan diagram kartesius. Diagram ini untuk melihat indikator -indikator yang dimasukkan kedalam penelitian ini mana yang masuk kedalam kuadran 1, kuadran 2, kuadran 3 dan kuadran 4 . Kuadran 1 yang dimaksud adalah kuadran yang merupakan prioritas utama dimana indikator yang masuk kedalam kuadran ini merupakan indikator yang menjadi perhatian penuh oleh produsen dalam meningkatkan performance barang yang dijual karena indokator yang masuk kedalam kuadran ini memliki tingkat harapan yang tinggi sedangkan tingkat kinerja yang dihasilkan oleh produk tersebut masih dibawah ekspetasi. Kuadran 2 maksudnya adalah pertahankan prestasi, ini maksudnya adalah ketika nilai tingkat kepentingan dan tingkat kinerja memiliki nilai yang sama yaitu ketika nilai harapan sama tinggi dengan nilai kinerja yang dihasilkan oleh produk yang dijual oleh produsen, sehingga atribut indikator tersebut harus dipertahankan apabila produsen ingin mempertahankan konsumen untuk tetap membeli produk yang dihalsikan. Kuadran 3 maskudnya adalah prioritas rendah, kuadran ini maksudnya adalah nilai tingkat harapan dan tingkat kinerja produk sama-sama rendah, dimana konsumen tidak terlalu mempehatikan indikator tersebut dan tingkat kinerja produk tersebutpun juga rendah sehingga tidak terlalu mempengaruhi terhadap tingkat kepuasan. Sedangkan kuadran 4 maksudnya adalah kuadran yang berlebihan dimana indicator yang masuk kedalam kuadran ini memiliki nilai kinerja yang sangat tinggi sedangkan harapan yang diharapkan oleh konsumen rendah. Maksudnya adalah indikator yang masuk kedalam kuadran ini lebih baik produsen jangan terlalu terfokus terhadap indikator tersebut karena konsumen tidak terlalu memperhatikan indikator tersebut

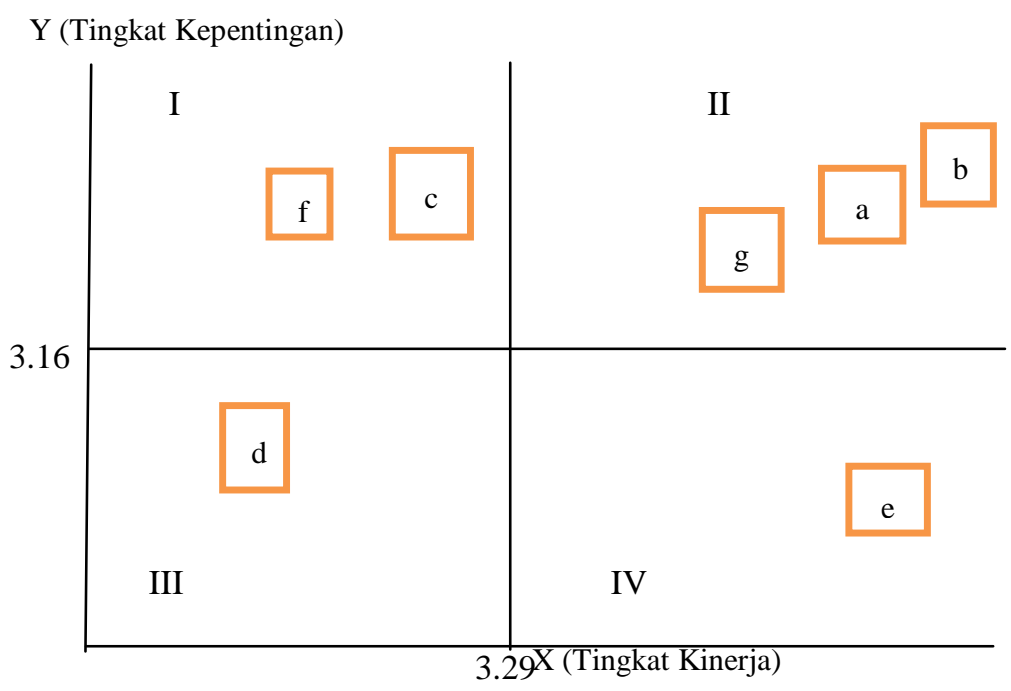


b. Gizi beras

c. Kemasan beras

d. Warna beras

e. Aroma nasi

f. Kebersihan beras

g. Bau beras

Sesuai dengan fungsi diagram kartesius yaitu untuk mengetahui posisi dari masing-masing atribut kedalam kuadran yang ada didalam diagram kartesius. Didalam diagram kartesius memiliki empat kuadran yaitu I (Prioritas Utama), II (pertahankan prestasi), III (prioritas rendah) dan IV (berlebihan). Untuk lebih jelasnya lihat penjelasan dibawah ini :

1. Prioritas Utama (I)

Atribut yang masuk pada kuadaran ini adalah atribut kebersihan beras (f), dan kemasan beras (d). indicator ini walaupun berdasarkan rasio dikatakan sudah memuaskan ternyata untuk peletakkan kedalam kuadaran kartesius masuk kedalam prioritas utama, dimana ternyata nilai tingkat harapan lebih tinggi ddaripada tingkat kinreja yang dihasilkan oleh produk tersebut. Sehingga apabila produsen dapat memperbaiki indicator kebersihan produk maka loyalitas konsumen terhadap produk tersebut akan semakin tinggi. Caranya mungkin sebelum dikemas produsen mempehatikan beras yang dimasukkan atau beras yang akan dijual dari sampahsampah sisa penggilingan beras tersebut. Dengan beras yang lebih bersih bebas dari sampahsampah sisa penggilingan padi maka konsumen akan lebih puas dan apabila konsumen puas dengan suatu produk maka konsumen akan menjadi loyal terhadap produk tersebut. Selain kebersihan beras yang masuk kedalam prioritas utama adalah kemasan beras. Kemasan yang dimaksud walaupun berdasarkan rasio sudah memuaskan ternyata dalam kuadran kartesius kemasn masuk kedalam prioritas utama dimana tingkat harapan lebih tinggi dari pada tingkat kinerja yang dihasilkan. Sehingga kemasan yang sudah ada dipasaran lebih diperbaiki lagi dan untuk meningkatkan kepuasan konsumen maka produsen lebih memperbaiki kemasan yang ada.

2. Pertahankan Prestasi (II)

Atribut yang ada pada kuadran iniberdasarkan hasil penelitian atribut yang masuk dalam kuadran pertahankan prestasi untuk beras adalah gizi beras (b), rasa beras (a), bau beras (g). dalam kuadran II ini produsen beras sudah dapat memenuhi kepuasan konsumen karena produsen sudah dapat menyeimbangi harapan konsumen yang tinggi dan kinerja produk juga tinggi.

3. Prioritas Rendah (III)

Atribut yang ada pada kuadran ini untuk beras warna beras (d). kuadran III ini adalah kuadran dimana tingkat kinerja dan tingkat harapan konsumen sama-sama rendah. Sehingga atribut yang berada pada kuadran ini tidak perlu diperbaiki kinerja nya karena tingkat harapan konsumen juga rendah terhadap atribut tersebut.

4. Berlebihan (IV)

Atribut yang ada pada kuadran ini untuk beras adalah aroma nasi (e). Kuadran IV ini adalah kuadran yang dimana tingkat kinerja sangat tinggi dibandingkan dengan tingkat harapan yang rendah.

\section{Kesimpulan}

Berdasarkan hasil pembahasan diatas didapatkan beberapa kesimpulan antara lain Atribut beras yang tidak puas adalah kebersihan beras. Hal ini disebabkan beras yang dijual biasanya masih terkandung batu, pasir, dan masih banyak kotoran yang ada didalam beras, hal ini terjadi ketika beras selesai digiling dan akan dimasukkan kedalam kemasan masuk juga batu dan pasir tersebut. Atribut beras yang puas yaitu atribut gizi beras, rasa beras, kemasan beras dan bau beras. Gizi beras seperti yang diktahui bahwa beras banyak terkandung gizi yang diperlukan oleh manusia dan konsumen tahu akan hal itu selain itu juga konsumen sudah paham akan tersebut. Rasa beras sudh puas karena beras yang ditanam didaerah tersebut sesuai dengan selelra masyarakat sekitar sehingga indicator ini sudah dapat memuaskan konsumen. Kemasan dan bau beras yang dijual 
sudah dapat memuaskan konsumen karena kemasn yang dijual praktis dan bau beras yang dijual tidak bau aspek.

\section{Daftar Pustaka}

[1] Ariani, Wahyu Dorethea. 2004. Pengendalian Kualitas Statistik. 11th ed. Yogyakarta.

[2] Amang, B dan Sawit, M.H. 1999. Kebijakan Beras Dan Pangan Nasional Pelajaran Dari Orde Baru Dan Era Reformasi. Jakarta: Institut Pertanian Bogor.

[3] Departemen Pertanian, 2011. Varietas Padi Unggul. Jakarta: Dinas Pertanian http://www.deptan.go.id

[4] (BPTP), Balai Pengkajian Teknologi Pertanian. 2011. Beras Unggul Lokal Sumatera Barat. Jakarta: Balai Pengkajian Teknologi Pertanian (BPTP). http://www.sumbar_bptp@yahoo.com

[5] Asgami, Putri. 2014. Analisis Tingkat Kepuasan Konsumen terhadap Beras di Kecamatan Pekanbaru Kota, Kota Pekanbaru. In Padang: Universitas Andalas.

[6] Rangkuti, F. 2003. Riset Pemasaran. Jakarta: Gramedia Pustaka Utama. 